\title{
Az erősebb a gyengébb nem?
}

\author{
Which is the stronger sex?
}

\author{
Szerzők: Csizmadia Péter $\bowtie$, Balku Eszter \\ Nemzeti Egészségfejlesztési Intézet
}

Beküldve: 2016.06.01.

\begin{abstract}
Összefoglaló: A cikkben a nemek közötti egészséggel kapcsolatos különbségek kerülnek bemutatásra a nemzetközi és a hazai adatgyűjtések alapján. A férfiak halálozási és halandósági adatai világszerte, így hazánkban is kedvezőtlenek, amely adatok összefüggésben állnak a férfiakkal szemben támasztott társadalmi elvárásokkal. A férfiak egészségének javításához egy új egészségügyi és egészség prevenciós szemléletre van szükség, amely igyekszik megváltoztatni a férfiak egészségmagatartását, növelve a szándékukat az egészségügyi szolgáltatások igénybevételére és csökkentve a rizikófaktorokat az egészségükkel kapcsolatban.

Kulcsszavak: nemek, férfi, nő, különbég, egészség
\end{abstract}

Summary: This article is an introduction which provides a concise overview of men, maleness and masculinity. We analyse national and international health data on the male population and provide a reviewing men's lifestyles, preventable risk factors, men's health behaviours. We present the overall state of men's health. We state the men's health is unnecessarily worse than can be expected. Finally we mention some good practices that can improve men's health.

Keywords: gender, man, woman, difference, health

\section{BEVEZETŐ}

A férfiak és a nők egészsége közti eltérések okainak vizsgálata a nyolcvanas években került a népegészségügy figyelmébe, elsősorban az angolszász országokban. A téma hazánkban sem ismeretlen, hiszen Métneki János és Simon Tamás tollából több cikk megjelent az Egészségfejlesztés folyóiratban 20032005 között. A jelen anyagban leírtak nagymértékben támaszkodnak ezekre az előzményekre, azokat naprakész adatokkal frissítve. ${ }^{1,2}$

A nők és a férfiak különböznek egymástól, ez vitathatatlan és szemmel látható tény. Beszélhetünk megfigyelhető, elsődleges, elsősorban biológiailag determinált különbségekről, illetve másodlagos jellegű, társadalmilag, kulturálisan meghatározott eltérésekről. E két tényezőt gyakran nem könnyű el- különíteni egymástól, ennek megfelelően a kutatók véleménye eltér abban, hogy a nemi különbségeket elsősorban biológiai vagy inkább társadalmi, kulturális meghatározottságúnak tekintik. A nemi különbségek közül számos velünk született tulajdonság. Nemünk kromoszomálisan meghatározott, és az intrauterin fejlődésben kialakult nemi státusszal születünk. A férfiak és a nők viselkedését és nemi szerepeit lényeges módon alakítják a biológiai diszpozíciók (anatómia, hormonrendszer, agyi lateralizáció').

A biológiai háttér hatással van a kulturális szerepekre is, és részt vesz a társadalmi szintű különbségek, a nemi szerepek, elvárások létrehozásában, a kulturális előírások és szabályok kialakításában, amelyek meghatározzák a társadalomban élő emberek szexuális attitűdjeit, szokásait.

'Szó szerint „oldalivá válás”, azaz a különböző funkciók, mint például a beszéd, az olvasás, az írás, vagy a számolás valamelyik agyféltekéhez köthetők. Ez a féltekei elrendeződés a lateralizáció. 


\section{MÓDSZERTAN}

A nemek közötti egészéggel kapcsolatos különbségek bemutatásához a nemzetközi és a hazai adatgyújtések, illetve felmérések eredményeit összegeztük ebben a cikkben.

\section{EREDMÉNYEK}

\section{Demográfiai különbségek}

A nemek szerinti különbségek között kell említenünk az emberi népességekben rendszeresen megfigyelhető fiúszületési többletet. Születéskor a fiúk aránya általában meghaladja a lányokét, de a férfi túlsúly egy idő után eltűnik. Magyarországon a 2011-ben született csecsemők között 4\%-kal több volt a fiú, mint a lány (100 csecsemőből 58 fiú és 42 lány), azonban ez a különbség a két nem között a kor előrehaladtával csökken, 40 éves kortól ez az arány megfordul, és női többlet jellemzi a magyar társadalmat. [1. ábra $\left.{ }^{4}\right]$

Ugyanezt a folyamatot egy másik adattal az özvegyi családi státusz változásával is érzékeltethetjük. A 40 évesnél idősebb korcsoportokban az özvegyek elsősorban a nők közül kerülnek ki, amely adat a férfiak korai halálozására utal. [2. ábra]

Mi lehet az oka ennek a változásnak? Napjaink társadalomtudományi diskurzusa a nemi szerepek különbségei kapcsán általában a nők hátrányára megnyilvánuló esélyegyenlőtlenségekre fókuszál, pedig van olyan terület, ahol a férfiak szorulnak nagyobb segítségre, ez pedig az egészség.

A statisztikai felmérések, de a közvetlen tapasztalatok is azt mutatják, hogy a háziorvosi- és a szakorvosi rendeléseken jóval kevesebb férfi jelentkezik egészségi problémáival, illetve kevesebben vesznek részt a szűrővizsgálatokban, mint a nők. Ebből arra is lehetne következtetni, hogy a férfiak egészségesebbek, kevesebb közöttük a beteg, mint a nők körében. A demográfiai és az egészségstatisztikai adatok viszont egyáltalán nem igazolják a férfiak jobb egészségi állapotát. Például a születéskor várható életkor adata, amely az egyik alapvető tájékoztató szám a lakosság egészségi állapotáról, világszerte és így Magyarországon is, a férfi lakosság több éves hátrányát mutatja a nőkkel szemben. [3. ábra]

A várható élettartamban mutatkozó különbségeknek részben biológiai okai vannak. Például a tesztoszteron, a férfi nemi hormon túltengése esetén fokozódik az agresszív viselkedés, míg a női nemi hormonnak, az ösztrogénnek számos egészségvédő hatása van. Az ösztrogén védi az érfalakat, így csökken a kardiovaszkuláris megbetegedések kialakulásának esélye. Ez magyarázatul szolgálhat arra, hogy a kardiovaszkuláris megbetegedések miért fordulnak elő nagyobb arányban általában a férfiak között. $^{3}$

1. ábra: A nemek arányának változása az életkor növekedésével ${ }^{4}$

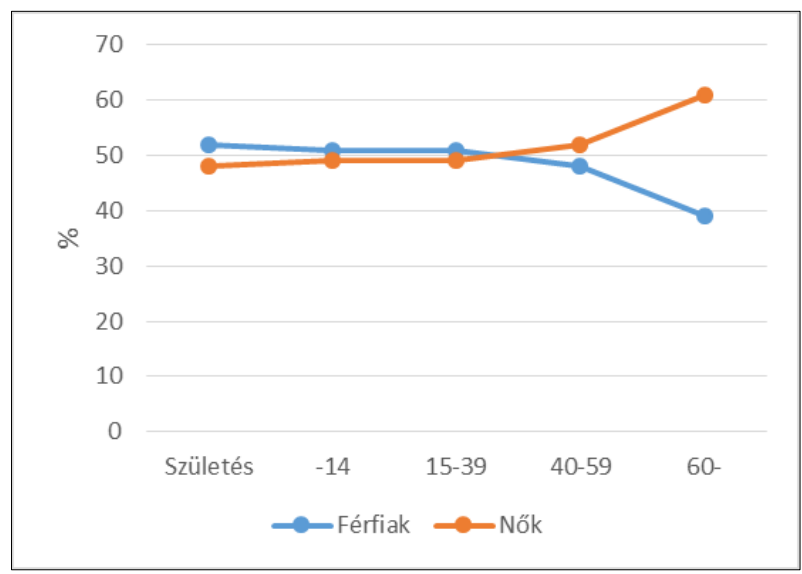

Forrás: KSH, Népszámlálás 2011

\section{2. ábra: Az özvegyek arányának változása az életkor elörehaladtával}

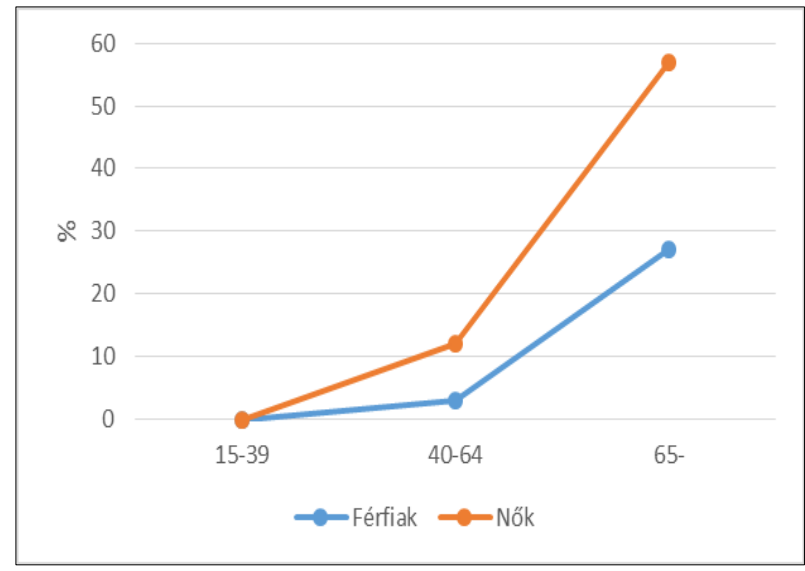

Forrás: KSH, Népszámlálás 2011 
3. ábra: Várható élettartam alakulása az OECD országokban, $2013^{5}$

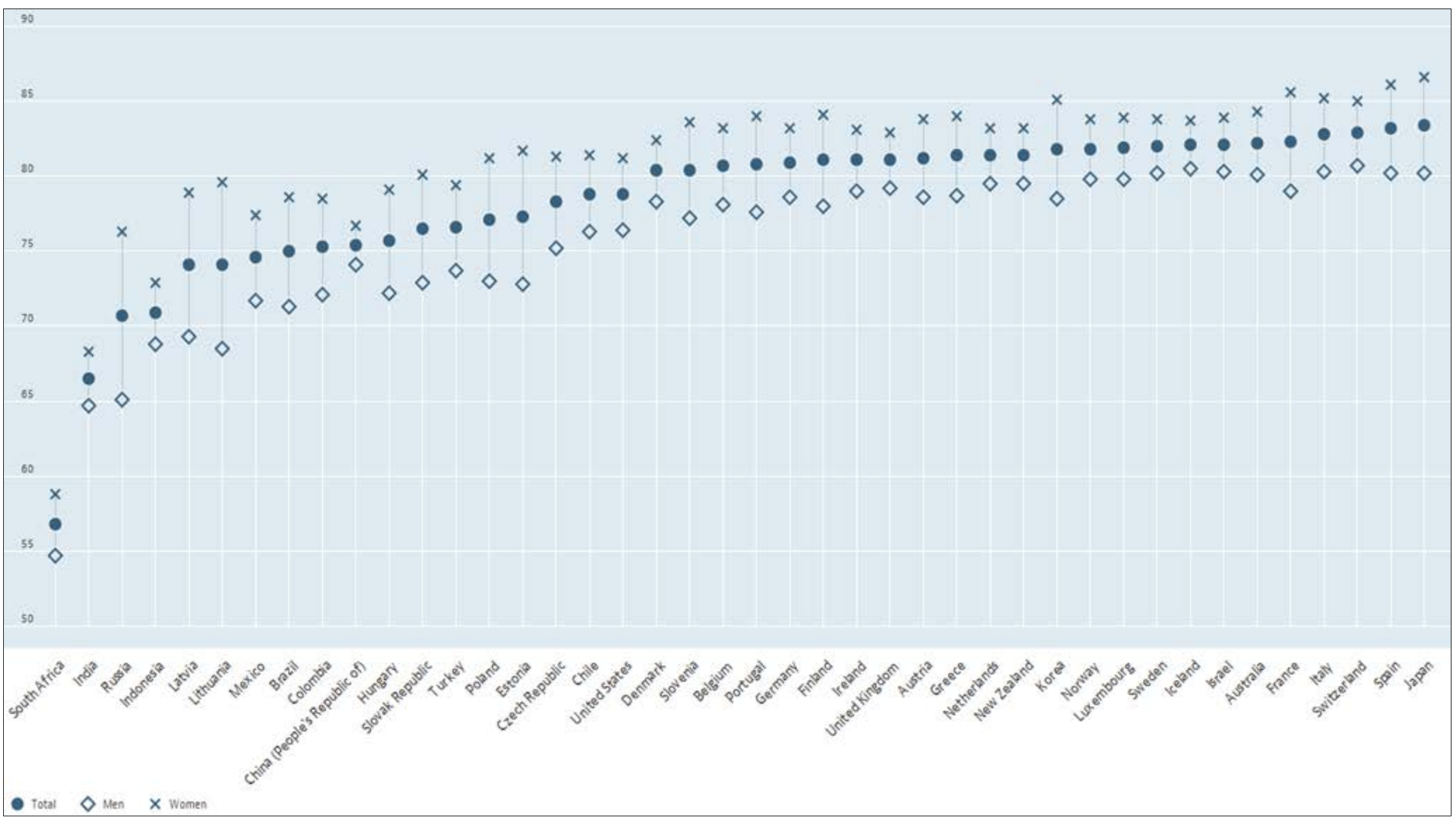

Forrás: OECD, Gender Data Portal 
A női nemi hormon protektív hatást fejt ki a bőrre, a nyálkahártyára. ${ }^{6,7}$

A férfiak és a nők szervezete között különbség van az immunválasz tekintetében is, mivel az ösztrogén stimulálja az immunválaszt, míg a tesztoszteron immunszuppresszív. ${ }^{8}$ Ez a hatás hajlamosabbá teheti a férfiakat a fertőző megbetegedésekre, amely a férfiak életstílusából s az egészségmagatartásából fakadó tényezők miatt növelheti az egészségügyi problémák kialakulásának kockázatát.

Részben szintén a biológia az oka annak is, hogy a nők gyakrabban találkoznak egészségügyi szakemberekkel, hiszen a fogamzásgátlás, a gyerekvállalás miatt sűrübben kell orvoshoz, védőnőhöz fordulniuk.

Amennyiben a 65 év előtt bekövetkezett, a korai standardizált halálozás nemenkénti eloszlását vizsgáljuk, akkor szintén arra jutunk, hogy a férfiak gyakrabban esnek áldozatul a daganatos, a szív- és érrendszeri megbetegedéseknek, a légzőrendszer kóros elváltozásainak, de gyakoribb a dohányzásnak tulajdonítható és külső okok miatti halálozás is, mint pl. a közlekedési balesetek. Lényegesen gyakoribb a férfiak körében az elkerülhető halálozások száma is, amely a megfelelő egészségügyi ellátás igénybevételével megelőzhető lenne. [4. ábra]

A halálozási adatokban mutatkozó éles eltérések magyarázatául, a pusztán biológiai indoklások elégtelenek. Az okok keresésében a szakemberek körében mindinkább a társadalmilag meghatározott nemi szerep, a gender vizsgálata került előtérbe.

4. ábra: Korai standardizált halálozás alakulása (SHA) nemenként, $2013^{9}$

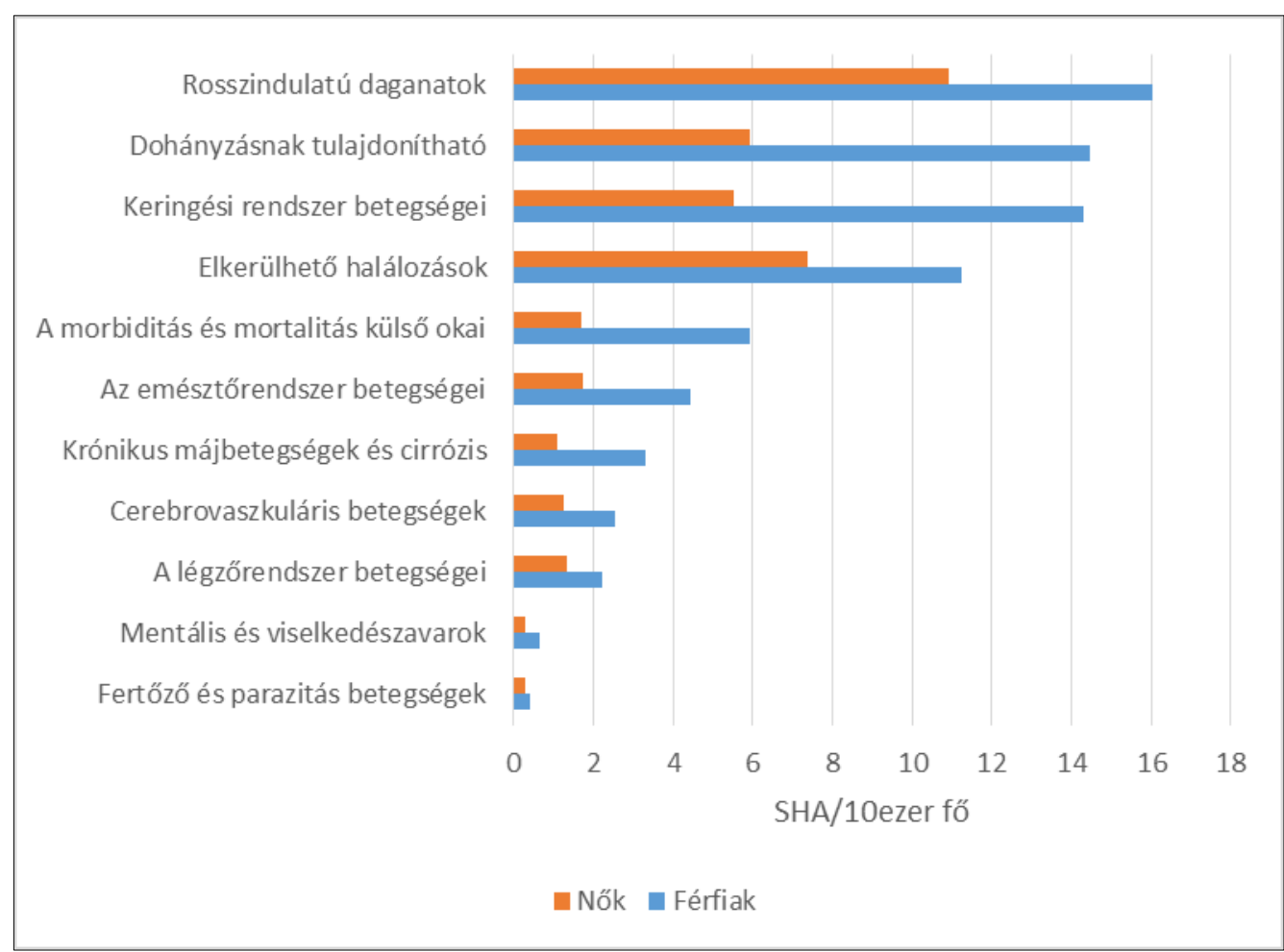

Forrás: NEFI, Halandósági adatbázis

Egészséggel kapcsolatos viselkedés

Fentiek értelmében a férfiak egészsége jelentősebb mértékben egyéni, magatartási, illetve társadalmi, környezeti tényezők által befolyásolt, mint a nőké.
A férfi társadalmi, és ebből adódóan önképét a magabiztosság, a kemény helytállás, a siker, a fizikai és lelki erő jellemzi. Ennek bizonyítására hajlamos akár az egészégét veszélyeztető helyzetek keresésére. ${ }^{10}$ A férfiak például többen dohányoznak, mint a nők, 
mindegy, hogy naponta, vagy alkalmanként gyújtanak csak rá. [1. táblázat]

1. táblázat: Dohányzási státuszok megoszlása nemek között ${ }^{11}$

\begin{tabular}{|c|c|c|}
\hline$\%$ & Férfi & Nö \\
\hline Naponta & 32,3 & 23,6 \\
\hline Alkalmi & 1,5 & 1,1 \\
\hline
\end{tabular}

Forrás: OEFI, Felnőtt Dohányzás Felmérés 2012

Már a fiúgyermekek szocializálásában is elfogadott az előbb említett jellemvonások kialakítása, akár úgy is, hogy az a gyermek egészségét veszélyeztető helyzetekkel párosul. Ebbe a képbe a testi és a lelki bajok, a gyengeség, a betegség nem illenek bele, férfiatlannak minősülnek, kudarcként átéltek. ${ }^{12} \mathrm{~A}$ férfiassággal kapcsolatos hiedelmek erősen befolyásolják a férfiakat az egészséggel kapcsolatos szolgáltatások igénybevételekor. ${ }^{13}$ Például egy hosszú távú követéses vizsgálat feltárta, hogy azok a fiatal férfiak, akiknek tradicionális hiedelmeik voltak a férfiasságról, szignifikánsabban ritkábban fordultak orvoshoz. ${ }^{14}$ Ez az egyik fő oka annak, hogy a férfiak ritkán, és legtöbbször későn fordulnak orvoshoz, illetve veszik igénybe az egészségügyi szolgáltatásokat. Az orvosi rendelési időbeosztás, a hosszú várakozási idő, ennek a munkaidővel való ütközése, nehezíti a szolgáltatások igénybevételét, és elriasztja a férfiak jelentős részét. ${ }^{15} 16$

Kutatások kiemelik az orvos és a férfi kliensek közti kommunikáció javításának jelentőségét. ${ }^{17}$ Ráadásul figyelembe kell venni, hogy a maszkulinitás ideológiája befolyásolhatja a férfi egészségügyi dolgozókat is, amelyből következően hajlamosak figyelmen kívül hagyni a férfi páciensek panaszait. ${ }^{18}$ Magyar adatok is megerősítik, hogy a férfiak ritkábban járnak házi- és szakorvoshoz, illetve fogorvoshoz, mint a nők. 100 nőből 80 volt háziorvosnál, 66 szakorvosnál, 40 fogorvosnál az elmúlt egy évben, míg 100 férfiból 71 volt háziorvosnál, 52 szakorvosnál és 35 fogorvosnál. ${ }^{19}$ Ezt a viselkedést támasztja alá a fentebb bemutatott elkerülhető halálozás alakulása is.
A betegség látszatát, az orvoshoz járkálást pedig sokan szintén a munkaalkalmasságuk bizonyítása miatt kerülik. Hasonló feszültséget jelent a munkahely megtartásáért folyó feszített, a férfiakat nagyobb mértékben érintő, egészséget is felőrlő helyzet, amely ugyanakkor még a betegség látszatának kerülését is megköveteli.

Ebből adódik az is, hogy a javasolt és indokolt életmódi változtatást nehezen fogadják el a férfiak. A tapasztalatok szerint nagyrészt tájékozatlanok testi és lelki egészségi problémáik megoldási lehetőségeiről, és ezért szkeptikusak ezeket illetően.

A férfiak életmódja is sok vonatkozásban különbözik a nőkétől. A táplálék mennyiségében, megválasztásában már az ifjúkortól egészségtelenebb szokásokat vesznek föl, amely abból adódhat, hogy a férfiak étkezéssel kapcsolatos ismeretei jóval korlátozottabbak, mint a nőké. ${ }^{20}$ Mindez a korán jelentkező túlsúlyhoz és ezzel együtt járó betegségekhez vezethet. A 2. táblázatban látható, a férfiak és a nők a túlsúly eloszlása.

\section{2. táblázat: Túlsúly eloszlása²1}

\begin{tabular}{|l|c|c|}
\hline$\%$ & Férfi & Nő \\
\hline Túlsúly és elhízás & 63 & 61 \\
\hline
\end{tabular}

Forrás: OÉTI, OTÁPii 2009

A 2009-es ELEFiii kutatás adatai közül a férfiak egészségtelenebb táplálkozását azzal szemléltethetjük, hogy ritkábban fogyasztanak zöldséget, de főként gyümölcsöt, mint a nők. [3. táblázat ${ }^{20} ; 4$. táblázat ${ }^{20}$ ]

A férfiaknak be kell tölteniük a férji, az apai, a munkahelyi szerepet, valamint vállalniuk az anyagi biztonságért a felelősséget. ${ }^{22} \mathrm{Ez}$ a teher nem egyszer súlyos pszichés állapothoz, depresszióhoz, alkoholizmushoz vezethet. ${ }^{23} \mathrm{~A}$ magyar adatok is igazolják, a férfiak gyakrabban fogyasztanak alkoholt, mint a nők. A férfiak 7,3\%-a tartozik a nagyivók közé, míg a nőknek csak a 0,3\%-a. [5. táblázat]

\footnotetext{
i Országos Táplálkozás és Tápláltsági Állapot Vizsgálat

iii Európai Lakossági Egészségfelmérés
} 
3. táblázat: Zöldség fogyasztásának gyakorisága ${ }^{20}$

\begin{tabular}{|l|l|l|}
\hline$\%$ & Férfi & \multicolumn{1}{|c|}{ Nő } \\
\hline Napi két vagy több alkalommal & 13,2 & 17,8 \\
\hline Naponta egyszer & 35,2 & 38,6 \\
\hline Legalább hetente négyszer & 25,4 & 22,3 \\
\hline Legalább hetente egyszer & 19,6 & 16,3 \\
\hline $\begin{array}{l}\text { Ritkábban, mint hetente egy- } \\
\text { szer }\end{array}$ & 5,7 & 4,2 \\
\hline Soha & 0,9 & 0,8 \\
\hline
\end{tabular}

Forrás: KSH, ELEF 2009

4. táblázat: Gyümölcs fogyasztásának gyakorisága ${ }^{20}$

\begin{tabular}{|l|l|l|}
\hline$\%$ & Férfi & Nő \\
\hline Napi két vagy több alkalommal & 25,8 & 35,3 \\
\hline Naponta egyszer & 35,4 & 39,1 \\
\hline Legalább hetente négyszer & 18,5 & 13,0 \\
\hline Legalább hetente egyszer & 14,3 & 7,9 \\
\hline Ritkábban, mint hetente egyszer & 5,4 & 4,1 \\
\hline Soha & 0,6 & 0,4 \\
\hline
\end{tabular}

Forrás: KSH, ELEF 2009

5. táblázat: Alkohol fogyasztás arányának megoszlása nemek között

\begin{tabular}{|l|l|l|}
\hline$\%$ & Férfi & Nó \\
\hline Nem fogyaszt & 25,2 & 52,3 \\
\hline Alkalmi ivó & 41,8 & 43,4 \\
\hline Mérsékelt ivó & 24,2 & 3,9 \\
\hline Nagyivó & 7,3 & 0,3 \\
\hline Mértéktelen ivó & 1,5 & 0 \\
\hline
\end{tabular}

Forrás: KSH, ELEF 2009
A férfiakra nehezedő eltérő elvárásokat Spéder Zsolt a következőképpen mutatja be:

„A közvélemény a férfiakkal szemben egyfajta kettős elvárásrendszert fogalmaz meg: egyidejűleg tartja szükségesnek a hagyományos kenyérkereső szerep betöltését, ugyanakkor részvételét is a gyermeknevelésben. ... Az a tény azonban, hogy interjúalanyaink fele nem tartja lényegesnek, hogy az apák aktívan részt vállaljanak a gyermekgondozásban, arra utal, hogy a modern apai vonások mégsem terjedtek el markánsan, és a hagyományos kenyérkereső férfi/apa képe mélyen beívódott a magyar társadalomba." 23

A hagyományos férfiképből adódó munkahelyi szerepek egészségi rizikóhelyzetet jelentenek egyes, elsősorban férfiakat foglalkoztató munkahelyeken, mint például az építőipar, a gyáripar és a raktározás, valamint a közlekedés, és a bányászat. Statisztikai adatok szerint a munkahelyi halálos baleseteknek 95\%-ban a férfiak az áldozatai, míg a nem halálos balesetek $76 \%$-ban sújtják a férfiakat. ${ }^{13}$

\section{Javasolt beavatkozás}

A cikkben taglalt, a férfiakat hátrányosan érintő egészségterhek megszüntetésére a következőket javasoljuk:

- A férfiak egészségi állapotának sokoldalú feltárása.

- A férfiak tudatosságának megerősítése saját egészségükről, fizikai és pszichés problémáiknak kezelhetőségéről.

- Az egészségügyi szolgáltatások igénybevételében és az életmódi változtatásokban jelentkező visszahúzódó, ellenző férfi magatartásnak a megváltoztatása.

- Az egészségügyi szolgáltatásokban, elsősorban az alapellátásban fokozott figyelem biztosítása a férfiak egészségi problémáinak kezelésére.

- A maszkulinitás nyomatékosítása helyett az egészségtudatosság hangsúlyozása, az egészségtudatosság legyen része a férfi kultúrának. A fentiek megvalósíthatóságára már nemzetközi jó gyakorlatok állnak rendelkezésre. Az Egyesült Királyságban a professzionális labdarúgó klubok részt vesznek olyan egészségintervenciókban, amelyek javíthatják a férfiak mentális egészségét. Ezek a beavatkozások sok esetben a fizikai aktivitás fokozásá- 
val igyekeznek hatást kiváltani, a labdarúgás népszerűségét kihasználva, a szurkolók labdarúgó klubokhoz való szoros kötődésére építve igyekeznek a lelki egészséget támogatni. Kutatások bizonyítják, hogy a labdarúgó klubok segíthetnek a lelki egészséghez kapcsolódó ellátásokhoz való hozzáférésben, különösen a fiatal férfiaknál, akik között az ilyen jellegű segítség elfogadása stigmatizáló lehet. ${ }^{24}$ A férfiak fizikai aktivitásának fokozására Skóciában egy 12 , hetes magatartás változtatásra koncentráló programot alakítottak ki, amely az egészséges életmód elemei között elsősorban a testsúlycsökkentés és a fizikai aktivitás népszerűsítésére összpontosított. A program hatékonyságát egy tudományos vizsgálat alátámasztotta. ${ }^{25}$

\section{ÖSSZEGZÉS}

A statisztikai adatok azt mutatják, a férfiak ritkábban veszik igénybe az egészségügyi szolgáltatásokat, de ez nem jelenti azt, hogy egészségesebbek, mint a nők. A férfiak rosszabb egészségi állapota magatartási, illetve társadalmi- és környezeti tényezők által meghatározott szerepükből adódik.

A férfiak szocializációja olyan, hogy eleve rizikóvállalóbbak, és ez a szocializációs folyamat eredményezi, hogy részt vesznek veszélyes viselkedésformák keresésében, amilyen a gyorshajtás, vagy a túlzott alkoholfogyasztás. Amikor a férfiak betegek lesznek - az elvárás miatt, amelynek megfelelve keménynek kell mutatkozniuk -, nem keresik a szakmai egészségügyi tanácsadást, vagy a segítséget. Ennek következményei tragikusak lehetnek. Egy új egészségügyi és egészségprevenciós szemléletre van szükség, amely számításba veszi a férfi nemi szerepét, és azt figyelembe véve igyekszik megváltozatni a férfiak egészségmagatartását, nem utolsó sorban abban a vonatkozásban, hogy növeljék a szándékukat az egészségügyi szolgáltatások igénybevételére, és csökkentsék az egészségüket veszélyeztető rizikófaktorokat

\footnotetext{
${ }^{1}$ Simon T. A gyengébb nem... Egészségfejlesztés, 2005, 4. szám; 7-9.

${ }^{2}$ Métneki J. Nemzetközi összefogás a férfiak egészségéért. Egészségfejlesztés. 2004, 3. szám; 5-7.

${ }^{3}$ Nadkarni, Suchita, Cooper, Dianne; Brancaleone, Vincenzo; Activation of the Annexin A1 Pathway Underlies the Protective Effects Exerted by Estrogen in Polymorphonuclear Leukocytes. Arterioscler Thromb Vasc Biol. 2011 Nov;31(11):2749-59.

${ }^{4}$ Központi Statisztikai Hivatal Népszámlálás 2011, http://www.ksh.hu/nepszamlalas/ (Elérve: 2016.06.27)

${ }^{5}$ http://www.oecd.org/gender/data/ (Elérve: 2016.06.27)

${ }^{6}$ Stevenson S, Thornton J. Effect of estrogens on skin aging and the potential role of SERMs. Clinical Interventions in Aging. 2007;2(3):283-297.

${ }^{7}$ Diebel M.E., Diebel L.N., Liberati D.M. Gender dimorphism in the gut: mucosal protection by estrogen stimulation of IgA transcytosis. J Trauma. 2011;71:474-479.

${ }^{8}$ Kovacs E.J., Messigham K.A.N. Influence of Alcohol and Gender on Immune Response National Institute on National Institute on Alcohol Abuse and Alcoholism (NIAAA), 2003

${ }^{9}$ Nemzeti Egészségfejlesztési Intézet Halandósági adatbázisa: http://www.egeszseg.hu/szakmai oldalak/oldal/adatbazisok/adatbazisok-halalozas-adatbazis/ (Elérve: 2016.06.27)

${ }^{10}$ Brody LR. The socialization of gender differences in emotional expression: Display rules, infant temperament, and differentiation. In: Fischer AH. (ed). Gender and Emotion: Social Psychological Perspectives. (pp.24-47), New York, Cambridge University Press, 2000

${ }^{11}$ Balku E., Demjén T., Vámos M., et al. Felnőtt Dohányzás Felmérés 2012, Budapest

${ }^{12}$ Ed. Alan White The State of Men's Health in Europe. Extended Report. 2011.

${ }^{13}$ Addis ME, Mahalik JR. Men, masculinity, and the contexts of help seeking. American Psychologist 2003, 58:5-14.

${ }^{14}$ Marcell A.V., Ford C.A., Pleck J.H., et al. Masculine beliefs, parental communication, and male adolescents' health care use. Paediatrics 2007, 119:966-975

${ }^{15}$ Piper S. The limitations of well men clinics for health education. Nursing Standard 1997, 11(30):47-49

${ }^{16}$ Leishman J., Dalziel A. Taking action to improve the health of Scottish Men. Men's Health Journal 2003, 2(3):90-93

${ }^{17}$ Dubé CE, Fuller BK, Rosen RK et al. Men's experiences of physical exams and cancer screening tests: a qualitative study. Preventive Medicine 2005, 40(6):628-635

${ }_{18}$ Moller-Leimkuhler A.M. Barriers to help seeking in men: a review of sociocultural and clinical literature with particular reference to depression. Journal of Affective Disorders 2002, 71:1-3, 1-9

${ }^{19}$ Európai Lakossági Egészségfelmérés 2009, http://www.ksh.hu/elef (Elérve: 2016.06.27)
} 
${ }^{20}$ Kiefer I, Rathmanner T, Kunze M Eating and dieting differences in men and women. Journal of Men's Health \& Gender 2013 2(2):194-201

${ }^{21}$ http://wwww.oeti.hu/?m1id=16\&m2id=169 (Elérve: 2016.06.27)

22 Spéder Zs. Ellentmondó elvárások között... Családi férfiszerepek, apaképek a mai Magyarországon. In Pongrácz Marietta - Nagy Ildikó (eds.): Szerepváltozások. Jelentés a nők és férfiak helyzetéröl. TÁRKI, Budapest, 2011, $207-228$.

${ }^{23}$ Freund P.E.S, McGuire M , Podhurst L.S.) Health, Illness, and the Social Body. Prentice, 1991

${ }^{24}$ Curran K., Rosenbaum S. , Parnell D., et. al. Tackling mental health: the role of professional football clubs, Sport in Society, 2016

${ }^{25}$ Hunt K., Wyke S., Gray C.M., et al. A gender-sensitised weight loss and healthy living programme for overweight and obese men delivered by Scottish Premier League football clubs (FFIT): a pragmatic randomised controlled trial Lancet 2014; 383: 1211-21 